\title{
KELEKATAN ANAK PADA ORANG TUA DALAM MENINGKATKAN PERKEMBANGAN KOGNITIF DAN HARGA DIRI
}

\author{
Amita Diananda \\ amitadiananda@rocketmail.com \\ Program Studi PIAUD STIT Islamic Village Tangerang - Indonesia
}

\begin{abstract}
Parental attachment does unequivocally have a pivotal relationship with emotion. Parent, especially a mom, is the first and foremost person who has the emotion bond with her child. This bond affects the most of the development of a child. The absent of fulfilment of emotion needs in caregiving of a child, such as a feeling of safety, love and/or compassion, attention, and appreciation, will take an innocent child to a stage of susceptibility that will drive him to be a "vulnerable child" that is a child with fragile personality, frail, fearful, lack of contentment and happiness, et cetera. Parental attachment in the period of growth and development can help challenging tasks so as to trigger cognitive development to the fullest and the growing of sense of self-esteem of a child. This research is using a qualitative approach and analysis, while the type of research is library research.
\end{abstract}

\section{Keyword: Attachment; Cognitive and Self-esteem.}

\begin{abstract}
Abstrak: Kelekatan pada orang tua berkaitan erat dengan emosi. Orang tua, terutama seorang ibu, adalah orang pertama dan terpenting yang memiliki ikatan emosi dengan anaknya. Ikatan ini mempengaruhi sebagian besar perkembangan anak. Tidak terpenuhinya kebutuhan emosi seorang anak dalam pengasuhan, seperti adanya rasa aman, cinta dan kasih sayang, perhatian, dan penghargaan, akan membawa seorang anak yang masih polos kepada suatu tahap yang ringkih dan menjadikannya sebagai "Vulnerable Child", yaitu anak dengan kepribadian yang rapuh, rentan atau lemah, mudah ketakutan, kecewa, sedih dan lain sebagainya. Kelekatan anak kepada orang tua dalam masa pertumbuhan dan perkembangan dapat membantu tugas-tugas yang menantang sehingga memicu perkembangan kognitif secara maksimal dan tumbuhnya rasa keberhargaan diri seorang anak. Penelitian ini menggunakan pendekatan dan analisa kualitatif, sedangkan jenis penelitiannya adalah penelitian kepustakaan.
\end{abstract}

\section{Kata Kunci: Kelekatan; Kognitif dan Harga Diri}

\section{A. PENDAHULUAN}

Keluarga adalah unit terkecil dalam masyarakat. Keluarga mempunyai peranan penting dalam pendidikan, pendidikan fisik, psikis, sosial dan spiritual bagi anak. Kasih sayang yang diterima anak paling awal adalah orang tua, saudara, dan orang-orang yang terdekat (kakek dan nenek) atau pengasuh. Ikatan sosial ini begitu hangat dan alami sehingga memberikan rasa aman yang merupakan kebutuhan 
ISTIGHNA, Vol. 3, No 2, Juli 2020 P-ISSN 1979-2824 E-ISSN 2655-8459

Homepage: http://e-journal.stit-islamic-village.ac.id/index.php/istighna

Amita Diananda

Kelekatan Anak Pada Orang Tua dalam Meningkatkan Perkembangan Kognitif dan Harga Diri

mendasar bagi anak untuk menjelajahi dunia serta menjalin hubungan dengan lingkungannya.

Dalam pandangan tabula rasa yang diajukan oleh filsuf Inggris John Lock, "anak -anak secara lahiriyah tidak buruk, tetapi sebaliknya mereka seperti selembar kertas kosong suatu tabula rasa." Lock yakin bahwa pengalaman masa anak-anak penting dalam menentukan karakteristik kelak menjadi orang dewasa. Dibutuhkan kehadiran dan pendampingan orang tua dalam meluangkan waktu kepada anakanak, dengan demikian diharapkan kelak menjadi anggota masyarakat yang dapat memberikan kontribusi. ${ }^{1}$

Dalam pertumbuhan dan perkembangan anak, kebutuhan kelekatan (attachment) terhadap orang tua terutama ibu dimulai dari sejak bayi bahkan sejak dalam kandungan sampai usia remaja dalam bentuk kelekatan yang berbeda-beda sesuai dengan kebutuhan usianya.

Teori kelekatan yang diperkenalkan oleh John Bowlby adalah suatu teori untuk mempelajari internalisasi pengaruh emosional anak dengan pengasuh utamanya. ${ }^{2}$ Walaupun penelitian awal ini kelekatan dilakukan untuk melihat pengaruh bayi dengan pengasuhnya, namun kelekatan tetap dibutuhkan anak meskipun telah menginjak remaja. Sebagaimana kelekatan pada bayi, kelekatan pada remaja berfungsi untuk memberikan rasa aman dan nyaman dalam diri seseorang, dengan mencari kelekatan dengan orang lain. Dalam penelitian kelekatan ini nantinya akan memberikan pengaruh pada afeksi, perilaku dan respon positif kognitif seseorang dalam kehidupannya sehari hari. ${ }^{3}$

Kelekatan anak tidak hanya kepada orang tua, namun bisa dengan pengasuh atau orang dewasa lainnya yang sering mengadakan interaksi. Dalam sebuah penelitian $20 \%$ kelekatan anak pada awal kehidupan bisa ditujukan pada seseorang yang sama sekali tidak berurusan dengan pengasuhan anak, namun bisa terjadi kepada seseorang yang dipilih anak sebagai objek kelekatan apabila: ${ }^{4}$

1. Sering mengadakan reaksi terhadap tingkah laku anak yang dimaksudkan untuk menarik perhatian.

2. Sering membuat interaksi secara spontan dengan anak.

Berkaitan dengan tanggungjawab orang tua kepada anak, kelekatan yang lebih dominan seharusnya orang tua (terutama ibu) terutama pada anak usia dini karena anak dengan orang tua mempunyai hubungan darah atau heriditas serta

\footnotetext{
${ }^{1}$ John W. Santrock, Life-Span Development Perkembangan Masa Hidup, ( Jakartra: Erlangga, 2002), Jilid 1, h. 8.

${ }^{2}$ Chuy, Wing-Yip \& Leung, Man-Tak (2016), Adult Attachment Internal Working Model of Self and Other, Self Esteem and Romantic Relationship Satisfaction in Chines Culture: By Multilevel-Multigroup Structural Equation Modelling, Applies Psychology Reading. DoI 10.1007/978-981-10-2796_14

${ }^{3}$ Ibid., h. 210

${ }^{4}$ P.J Monk, A.M.P. Knoers, (et.all), Psikologi Perkembangan, (Yogyakarta: Gadjah mada Universyty Phress), h. 71.
} 
ISTIGHNA, Vol. 3, No 2, Juli 2020 P-ISSN 1979-2824 E-ISSN 2655-8459

Homepage: http://e-journal.stit-islamic-village.ac.id/index.php/istighna

Amita Diananda

Kelekatan Anak Pada Orang Tua dalam Meningkatkan Perkembangan Kognitif

dan Harga Diri

ikatan emosional sejak dalam kandungan. Namun tidak menutup kemungkinan kelekatan anak dengan orang dewasa lainnya, dan hal ini bisa terjadi apabila anak sering berinteraksi dengannya.

Pentingnya kelekatan pada masa awal kehidupan anak berawal dari karya seorang psikiater Inggris, John Bowlby (1969-1973), yang mengamati efek dahsyatnya pada bayi yang dibesarkan dalam kondisi tertekan tanpa pelukan seorang pengasuh dalam suatu panti asuhan akan berdampak buruk pada bayi. Mereka dibesarkan di dalam kondisi tertekan dan mengalami perkembangan kognitif yang tidak sehat. Hasil penelitian menyebutkan, bahwa bayi-bayi tersebut terlihat sehat secara fisik, namun terlihat putus asa, kesepian, dan tidak bersemangat secara emosional. Bowlby berpendapat, dengan membangun kelekatan dengan pengasuhnya, anak-anak mendapatkan fondasi yang aman untuk kembali ketika mereka merasa takut. Idealnya bayi akan menemukan keseimbangan diantara menjelajahi dan mempelajari lingkungan yang baru. ${ }^{5}$

Kebutuhan kelekatan menurut Bowlby seperti halnya vitamin dan protein yang penting sekali untuk perkembangan fisik dan psikis yang sehat, karena kelekatan kasih sayang ibu adalah esensial. ${ }^{6}$ Pada akhirnya kelekatan yang kuat diharapkan dapat mengembangkan harga diri, emosi, kognitif, moral dan pro-sosial pada anak dalam menjalin hubungan interpersonal dan intrapersonal.

Hasil penelitian Crittenden (dalam McConnell \& Moss, 2011) membuktikan bahwa faktor rasio income-to-needs lebih tinggi yang dimiliki keluarga dengan tingkat pendidikan rendah dan kurang peka, ikut berperan dalam perubahan pola kelekatan anak usia 36 bulan dari rasa aman (secure) menjadi rasa tidak aman (insecure). ${ }^{7}$

Kelekatan yang aman antara anak dengan orang tua menimbulkan kontrol emosi yang baik bagi anak. Hal ini dapat dilihat dalam penelitian yang menunjukkan bahwa anak-anak membentuk ikatan emosional yang kuat dengan orang tuanya dan mempunyai kemampuan yang lebih baik dalam bersosialisasi dan menunjukkan empati yang lebih besar terhadap orang lain, jauh dari depresi, jauh dari penyalahgunaan obat terlarang/alkohol. ${ }^{8}$

${ }^{5}$ Padang Mursalin dkk, Psikologi,( Jakarta: Penerbit Erlangg, 2016), h. 156. Ed.11.Jilid 2.

${ }^{6}$ Ibid., h. 110.

${ }^{7}$ McConnell, M. \& Moss, E. (2011). Attachment across the life span: factors that contribute to stability and change. Australian Journal of Educational \& Developmental Psychology, pp. 6077 diakses tanggal 23 Maret 2012

http://www.newcastle.edu.au/Resources/Research\%20Centres/SORTI/Journals/AJEDP/V ol\%2011/V11 McConnell\%20\&\%20Moss.pdf

${ }^{8}$ Teressa M McDevvit, Jeanes Elliss Omrod, Child Development and Education (New Jersey Colombo, Ohio, Merril Prentice Hall, 2002) h. 458. 
ISTIGHNA, Vol. 3, No 2, Juli 2020 P-ISSN 1979-2824 E-ISSN 2655-8459

Homepage: http://e-journal.stit-islamic-village.ac.id/index.php/istighna

Amita Diananda

Kelekatan Anak Pada Orang Tua dalam Meningkatkan Perkembangan Kognitif dan Harga Diri

Apabila kelekatan (attachment) sudah terbentuk dengan baik, maka mudah bagi orang tua dalam memberikan pendidikan dalam bentuk yang lainnya. Misalkan, dalam perilaku pro-sosial, membentuk harga diri dan lain sebagainya.

Saat anak menerima berbagai informasi dan masuk dalam data memorinya bagaimana ia diperlakukan baik atau buruk oleh orang lain maka anak akan menegaskan kembali tentang bagaimana perasaannya tentang diri sendiri. Apabila, anak merasa nyaman dengan dirinya sendiri karena ia diperlakukan baik oleh keluarganya, maka ia akan menganggap perlakuan yang baik juga dari yang lainnya Misalkan bagaiman seorang guru bersikap terhadapnya maka ia merasa seperti diperlakukan baik oleh keluarganya, maka ia wujudkan perasaan itu di ruang kelas dengan bersikap bahagia dan kooperatif. Ini pada gilirannya, membuat meraka yang berada di sekelilingnya memperlakukan dirinya secara positif. ${ }^{9}$

Begitupun sebaliknya, seorang anak merasa dirinya negatif karena caranya diperlakukan dikeluarganya, maka perlakuan baikpun mungkin tidak mengubah harga dirinya. Ia mungkin mewujudkan perasaan negatifnya tentang diri sendiri dengan bersikap agresif ke anak-anak yang lain, mengacaukan kegiatan, atau dengan menyendiri dan tidak berpartisipasi. Anak tersebut membuat respon negatif yang semakin menguatkan perasaan tidak berguna. ${ }^{10}$

Banyak penelitian yang menyebutkan pentingnya kelekatan anak tidak hanya anak usia dini tetapi kelekatan anak remaja dengan orangtuanya. Salah satu contohnya penelitian yang dilakukan oleh Winarti, Choliwati \& Istianti pada tahun 2004. ${ }^{11}$ Penelitian ini dilakukan di salah satu SMP Negeri Tangerang. Sekolah ini berada di dalam lingkungan perumahan yang tidak baik. Hal ini ditandai dengan seringnya terjadi perkelahian antar kelompok masyarakat, yang disebabkan oleh karena saling ejek mengejek pada anak-anak. Meskipun masalahnya tidak terjadi korban, dan dapat diselesaikan secara kekeluargaan, namun seringkali melibatkan remaja awal yang ada di lingkungan ini. Hasil penelitian menyebutkan bahwa, dengan adanya kelekatan antara orang tua dan anak laki-laki remaja awal, akan membantu meningkatkan kecerdasan emosional anak.

${ }^{9}$ Ibid., h. 54

${ }^{10}$ Ibid.., h. 55.

${ }^{11}$ Winarti, Kholilawati \& Istianti(2014), Hubungan Kelekatan Orangtua Dengan Anak Terhadap Kecerdasan Emosional Remaja laki-laki di SMP, JKKP: Jurnal Kesehatan Keluarga dan Pendidikan, DOI:doi.org/10.21009/JKKP.012.03. 
Amita Diananda Kelekatan Anak Pada Orang Tua dalam Meningkatkan Perkembangan Kognitif dan Harga Diri

\section{B. HASIL DAN PEMBAHASAN}

\section{Pengertian Kelekatan dan Konsep Dasar Kelekatan}

Kelekatan (attachment) adalah suatu kondisi dimana seseorang secara psikologis, emosional dan/atau batiniah merasa dekat atau memiliki ketergantungan atau hubungan yang bersifat khusus kepada seseorang yang dapat menghadirkan kenyamanan, ketentraman, keamanan, dan/atau inspirasi. Orang yang menjadi tempat bergantung ini tidak hanya orang tua, khususnya ibu, saudara atau pengasuh, tetapi juga orang-orang yang memberikan perhatian khusus, orangorang yang selalu memberikan motivasi atau dorongan semangat, orang-orang yang selalu membela atau memperjuangkan dengan tulus kepentingan-kepentingannya. ${ }^{12}$

Perspektif evolusioner dalam teori kelekatan Bowlby menyatakan bahwa kelekatan memiliki fungsi protektif sehingga bayi telah memiliki kecenderungan biologis untuk mendekat pada orangtuanya saat ia dalam situasi tertekan. ${ }^{13}$

Bowlby, tokoh yang mencetuskan teori kelekatan ini pada tahun 1950-an, merumuskan 3 (tiga) konsep dasar kelekatan, yaitu sebagai berikut:

a. Kelekatan berfungsi sebagai suatu bentuk pertahanan terhadap perilaku kejahatan. Prinsip dibalik munculnya kelekatan adalah kebutuhan akan perasaan aman.

b. Perasaan aman yang dihasilkan dari kelekatan yang positif (secure attachment) memiliki hubungan erat dengan kemampuan untuk mengembangkan kreatifitas dan eksplorasi (menguasai lingkungan). Heard and Lake, pada tahun 1986, mengungkapkan hasil penelitian mereka yang kemudian dicatat oleh Jerome Holmes, mengindikasikan bahwa hanya anakanak yang kebutuhan attachment-nya telah terpenuhi, yang memiliki kemampuan untuk mengembangkan dan mentransfer figur kelekatannya kepada seseorang menuju kepada kelekatan pada lingkungan sekitarnya. Sehingga ketika ia menginjak usia remaja, anak tersebut akan memiliki kemampuan bergaul, memiliki peningkatan kepercayaan kepada orang lain, dan memiliki hubungan sosial yang lebih baik, bahkan sangat baik.

c. Kelekatan bukanlah kebutuhan anak yang memungkinkan terjadinya pertumbuhan anak lebih cepat, tetapi merupakan kebutuhan yang terpendam sepanjang hidup manusia. ${ }^{14}$

\footnotetext{
${ }^{12}$ P.J Monk, A.M.P. Knoers, (et.all), Psikologi Perkembangan. Op.cit., h. 110

${ }^{13}$ Cassidy, J. 2008. The nature of the child's ties. Dalam Handbook of attachment: Theory, research, and clinical application. 2nd ed. J. Cassidy \& P.R. Shaver (Eds.). New York: The Guildford Press

${ }^{14} \mathrm{https} / / /$ www.universitaspsikologi.com/2018/05/teori-psikologi-perkembangan-attacment-

kelekatan.html
} 
Amita Diananda

Kelekatan Anak Pada Orang Tua dalam Meningkatkan Perkembangan Kognitif dan Harga Diri

Walaupun kelekatan merupakan sebuah ikatan yang emosional, namun tidak semua hubungan yang bersifat emosional dapat diartikan sebagai kelekatan. Ainsworth menjelaskan bahwa terdapat beberapa ciri khusus yang menunjukkan adanya hubungan kelekatan antara seorang anak dengan figur tertentu, yaitu hubungan tersebut bertahan cukup lama, ikatan tetap ada walaupun figur lekat tidak tampak dalam jangkauan pandang anak atau bahkan jika figur ini digantikan oleh orang lain, serta hubungan ini menimbulkan rasa aman (secure). ${ }^{15}$

Kelekatan merupakan hubungan yang didukung oleh tingkah laku lekat (attachment behavior) yang dirancang untuk memelihara hubungan tersebut. Karena anak masih dalam masa kebergantungan kepada seseorang, dan masih membutuhkan rasa aman untuk menjaga dirinya maka anak akan mencari kedekatan atau hubungan dengan figur lekat terutama bila ia merasa takut, sakit, lelah, tertekan dan juga ketika membutuhkan perhatian dan perlindungan.

Quality time dan quantity time sama pentingnya, sosok ayah dan sosok ibu harus hadir utuh pada tahap pertumbuhan dan perkembangan anak. Untuk mencurahkan cinta dan kelekatan terhadap ayah bundanya, selain itu ada penguatan identitas gender untuk fitrah seksualitasnya.

Kelekatan (attachment) merupakan ciri khas manusia. Manusia mempunyai ciri khas untuk berinteraksi sosial, untuk mengadakan manipulasi dan eksplorasi benda-benda disekitar, untuk mencari kontak dengan manusia yang lain. Berawal dari ciri-ciri khas tersebut kemudian mendatangkan kesesuaian-kesesuaian antara dirinya dengan lingkungannya, sehingga muncul lah suatu sikap atau tingkah laku yang menghadirkan atau menggambarkan adanya kelekatan. Tingkah laku lekat sesungguhnya adalah sesuatu yang fitrah yang sudah ada sejak dini, sejak seorang anak dilahirkan, bahkan terjadi sebelum adanya proses-proses belajar yang merupakan tahapan lanjutan dari kehidupan seorang anak. Kelekatan dini yang bersifat fitrah ini timbul dari suatu kebutuhan indrawi atau intuitif seorang anak (bayi), seperti kebutuhan akan makan dan minum (seperti tingkah laku mencari puting susu ibu), kebutuhan kehangatan yang menghadirkan kenyaman, dan sebagainya. Sehingga kelekatan dini ini dipandang sebagai suatu kondisi yang bersifat struktural yang timbul dari hubungan ibu dan anak. ${ }^{16}$

Terdapat dua faktor yang mendasari terbentuknya kasih sayang yang nyaman, pertama, orang tua yang sensitif terhadap kebutuhan anaknya pada masa bayi biasanya melanjutkan kasih sayang itu sampai pada masa perkembangan berikutnya. Dengan kata lain kasih sayang yang nyaman berkembang menjadi

${ }^{15}$ Adiyanti, M. G. (1989). Attachment Behavior in Children: Perkembangan kelekatan anak. Tesis. (Yogyakarta: Fakultas Pasca Sarjana Universitas Gadjah Mada)

${ }^{16}$ F.J Monk (att all), Psikologi Perkembangan. Op.Cit.,h. 109. 
Amita Diananda Kelekatan Anak Pada Orang Tua dalam Meningkatkan Perkembangan Kognitif dan Harga Diri

hubungan yang solid dan penuh cinta. Kedua, anak dengan kenyamanan kasih sayang akan memiliki harapan positif dengan orang lain dan membawa harapan positif ini dalam suatu hubungan. ${ }^{17}$

Kasih sayang dari orang tua atau pengasuh lainnya merupakan dasar bagi hubungan sosial emosional. Dengan kasih sayang yang cukup anak akan merasa aman dan dapat membentengi diri dari perasaaan nyaman atau tidak nyaman dalam kehidupannya. $^{18}$

Kelekatan dimulai dengan sentuhan dan pelukan fisik diantara bayi dan orang tua. Kenyamanan akibat sentuhan (contact comfort), yakni kesenangan yang diakibatkan sentuhan dan gendongan, tidak hanya sangat penting bagi bayi yang baru lahir, tetapi juga untuk semua orang selama hidupnya karena hal tersebut melepaskan endorfin yang memproduksi perasaan senang dan endorfin yang mengurangi rasa stress dalam jumlah besar. Pada latar belakang rumah sakit, sentuhan yang paling lembut dari perawat atau dokter pada lengan dan dahi pasien mampu menenangkan pasien secara psikologis dan menurunkan tekanan darah. ${ }^{19}$

Perasaan nyaman dengan kelekatan anak ada persyaratannya yaitu; Pertama, figur pengganti harus dikenal oleh anak. Kedua, anaknya sendiri harus dalam kondisi sehat. Ketiga, ia harus tahu dimana ibunya dan bahwa ia dengan mudah dapat mencari kontak kembali padanya. ${ }^{20}$

Menurut teori difirensial, anak dianggap relatif mempunyai kelekatan dengan ibunya sampai kurang lebih 6 tahun, baru sesudahnya anak akan mengadakan ikatan dengan orang-orang dewasa yang lainnya. ${ }^{21}$ Dengan kata lain attachment diperlukan di sepanjang hidup manusia dalam bentuk yang berbeda.

\section{Perkembangan Kognitif Pada Anak}

Kognitif merupakan kata sifat yang berasal dari kata kognisi (benda). Pada Kamus Besar Bahasa Indonesia, kognisi diartikan sebagai 4 (empat) pengertian, yaitu: ${ }^{22}$

a. Kegiatan atau proses memperoleh pengetahuan, termasuk kesadaran dan perasaan.

b. Usaha menggali suatu pengetahuan melalui pengalamannya sendiri.

c. Proses pengenalan dan penafsiran lingkungan oleh seseorang.

d. Hasil perolehan pengetahuan.

\footnotetext{
${ }^{17}$ Teressa M.McDevitt, Jeanes Ellis Ormrod, Op.Cit., h. 323

${ }^{18}$ Ibid.

${ }^{19}$ Padang Mursalin dkk, Psikologi., op.cit h. 156

${ }^{20}$ F.J Monk (att all), Psikologi Perkembangan. Op.Cit., h. 111.

${ }^{21}$ Ibid., h.110.

${ }^{22}$ Novan Ardy Wiyani, Psikologi Perkembangan Anak Usia Dini (Yogyakarta, Gava Media, 2014), h. 61
} 
ISTIGHNA, Vol. 3, No 2, Juli 2020 P-ISSN 1979-2824 E-ISSN 2655-8459

Homepage: http://e-journal.stit-islamic-village.ac.id/index.php/istighna

Amita Diananda Kelekatan Anak Pada Orang Tua dalam Meningkatkan Perkembangan Kognitif dan Harga Diri

Kognisi juga dapat diartikan sebagai suatu kemampuan untuk mengenal secara lebih baik hal-hal yang bersifat internal maupun eksternal melalui suatu proses berfikir atau dengan memanfaatkan segala kecerdasan yang dimilikinya. Kemampuan untuk mengenal ini pada gilirannya akan mendatangkan pada dirinya suatu konsep, strategi dan ketrampilan untuk memahami, menyikapi dan/atau menyiasati apa yang terjadi pada lingkungannya yang dapat berdampak langsung pada kelangsungan kehidupannya melalui serangkaian proses berfikir dan penggunaan daya ingat yang berlangsung secara berkesinambungan mulai dari menyelesaikan hal-hal yang bersifat sederhana sampai kepada hal-hal yang bersifat kompleks. $^{23}$

Setiap anak dibekali Tuhan dengan potensi akal untuk berfikir. Anak dengan potensi tersebut akan mengeksplorasi dirinya sendiri, dengan orang lain, dengan hewan dan tumbuhan, serta berbagai benda disekitarnya sehingga mereka dapat memperoleh ilmu pengetahuan.

Pengertian potensi sendiri adalah kondisi laten yang memerlukan pengetahuan dan latihan untuk menjadi kompetensi. ${ }^{24}$ Potensi akan berkembang baik dengan pendidikan dan pembelajaran melalui pengalaman-pengalaman.

Tuhan telah membekali setiap anak yang lahir dengan potensi baik. Dalam Al-Qur'an Allah SWT berfirman:

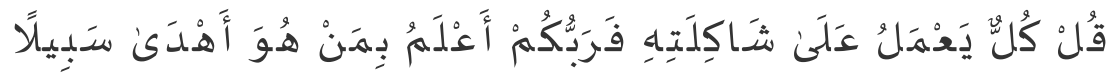

Katakanlah: "Tiap-tiap orang berbuat menurut keadaannya masing-masing (pembawaannya)". Maka Tuhanmu lebih mengetahui siapa yang lebih benar jalannya. (Q.S. Al-Isra', ayat 84)

Ada sebuah hadits yang berbunyi:

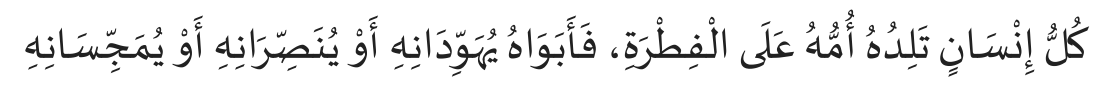

"Setiap manusia dilahirkan ibunya di atas fitrah. Kedua orang tuanya yang menjadikannya Yahudi, Nasrani, atau Majusi”. (Hadits ini diriwayatkan oleh al-Baihaqi dan ath-Thabarani dalam al-Mu'jamul Kabir. Al-Imam Muslim rahimahullah $)^{25}$

Dapat dijelaskan dalil tersebut di atas yang bersumber dari Alqur'an dan Hadits bahwa Tuhan telah membekali manusia dengan potensi bawaannya dan

23 S.R.R. Pujiati dan Alzena Masykouri, Mengasah Kecerdasan di usia 0-2 Tahun, (Jakarta: Dirjen PAUDNI, 2011), h.6

${ }^{24}$ Okina Fitriani, Enlightening Parenting (Jakarta: PT Serambi alam semester, 2018) h.51.

${ }^{25}$ https://asysyariah.com/anak-lahir-di-atas-fitrah/ 
ISTIGHNA, Vol. 3, No 2, Juli 2020 P-ISSN 1979-2824 E-ISSN 2655-8459

Homepage: http://e-journal.stit-islamic-village.ac.id/index.php/istighna

Amita Diananda

Kelekatan Anak Pada Orang Tua dalam Meningkatkan Perkembangan Kognitif

dan Harga Diri

setiap potensi tersebut harus dididik dikembangkan dengan lingkungan pendidikan karena fitrah manusia adalah makhluk pembelajar.

Orang tua sebagai pendidik yang sejati, mendidik anak sesuai dengan fitrah atau potensi bawaan sejak lahir. Mendidik anak bukan sebagai upaya merekayasa sehingga orang tua bersikap mendominasi, memanipulasi, mengintervensi, menjejalkan (outside in) bahkan merusak potensi sendiri, namun mendidik sesuai fitrah atau potensi adalah menemani, merawat, menumbuhkan, membangkitkan (inside out) benih agar menjadi pohon yang baik yang akarnya menghunjam dalam ketanah dan batangnya menjulang, daunnya rimbun menaungi siapapun dibawahnya, buahnya lebat memberi peran manfaat sampai akhir hayat. ${ }^{26}$

Berkaitan dengan fitrah atau potensi anak sebagai pembelajar, pada tahun 1920 ahli biologi Swiss Jean Piaget mulai melakukan studi tanggapan anak-anak terhadap berbagai macam permasalahan dan wawasan yang mendalam dan unik mengenai bagaimana anak-anak berfikir dan belajar tentang dunia disekitar mereka.

Dalam teori perkembangan kognitif oleh Jean Piaget tersebut dikatakan bahwa setiap anak fitrahnya adalah pembelajar yang aktif dan termotivasi. Artinya Jean Piaget meyakini bahwa anak-anak secara alami memiliki ketertarikan terhadap dunia dan secara aktif anak terus menerus bereksperimen dengan objek-objek yang mereka jumpai. Mereka memanipulasi objek-objek tersebut dan mengamati dampak tindakan mereka. Anak-anak mengkonstruksi pengetahuan mereka berdasarkan pengalaman. Mereka menggabungkan pengalaman-pengalaman mereka menjadi suatu pandangan terintegrasi mengenai cara kerja dunia disekitar mereka. Sebagai contoh melalui pengamatan bahwa makanan, mainan, dan objekobjek yang lainnya jatuh ke bawah (tidak pernah ke atas) ketika dijatuhkan, anakanak mulai membentuk pemahaman dasar mengeni gravitasi. ${ }^{27}$

Orang tua mendampingi dan tidak perlu cemas dan khawatir akan semangat belajar anak yang kadang menurun atau malas belajar. Karena sesungguhnya fitrah anak sebagai pembelajar yang aktif sampai kapanpun. Maka jika nampak tidak semangat belajar, maka jangan sibuk bagaimana membuatnya semangat belajar tetapi mengapa anak tidak semangat belajar, apa penghalang fitrahnya.

Orang tua harus menurunkan ego serendahnya, menajamkan intuisi dan nurani serta fitrah keayah-bundaan dengan terus menggali perasaannya, frustasinya, harapannya, jeritan hatinya, minat dan sifat uniknya, hal-hal mendalam yang dibutuhkan dan temukan pemicu kehebatannya.

${ }^{26}$ Hari Santoso, Fitrah Based Education (Bekasi, yayasan Cahaya Timur, 2018), h. iv
${ }^{27}$ Jeanne Ellis Ormrod, Psikologi Pendidikan, (Jakarta: Penerbit Erlangga, 2008), h. 40 
ISTIGHNA, Vol. 3, No 2, Juli 2020 P-ISSN 1979-2824 E-ISSN 2655-8459

Homepage: http://e-journal.stit-islamic-village.ac.id/index.php/istighna

Amita Diananda

Kelekatan Anak Pada Orang Tua dalam Meningkatkan Perkembangan Kognitif dan Harga Diri

Ada beberapa hal yang perlu difahami oleh orang tua, guru atau pengasuh yang terdekat dengan anak apabila malas belajar yaitu:

a. Objek belajar tidak sesuai bakatnya atau tahap usianya;

b. Gurunya tidak dekat dengannya;

c. Orangtuanya banyak memaksanya;

d. Memberi semangat yang tidak dibutuhkannya;

e. Kurang dialog dan teladan dalam belajar;

f. Lingkungan belajarnya tidak cocok dengannya;

g. Gaya belajar tidak difasilitasi;

h. Istirahat karena beban akademis yang berat;

i. Anak punya masalah dengan ego dan sosialnya;

j. Anak tidak punya komunitas belajar yang seru;

k. Kurang sehat atau kurang nutrisi;

1. Tidak punya tokoh teladan yang dikagumi, dll.

Potensi belajar anak dapat dikembangkan dengan baik apabila lingkungan dapat menumbuhkan gairah belajarnya. Peran orang tua disini adalah yang utama karena mempunyai kelekatan khusus yaitu hereditas dan ikatan emosi sehingga lebih banyak waktu untuk memberi kesempatan dalam menjelajah dan mengeksplor imajinatif positifnya.

\section{Fungsi Keluarga}

Keluarga adalah pusat dari kehidupan sebagian kegiatan anak anak. Keluarga adalah "pusat pembelajaran dan pusat mendapatkan kasih sayang" dimana anakanak mendapatkan perhatian, bimbingan, dukungan, dan sumber daya yang mereka butuhkan untuk menangani banyak tugas dan tantangan hidup.

Orangtua adalah figur signifikan atau orang yang berpengaruh dalam hidup anak. Mereka adalah "agen sosialisasi" karena orang tua mempunyai intensitas waktu yang lebih serta menjadi contoh dalam perilaku anak dalam keseharian.

Sosialisasi yang baik bagi anak-anak adalah orangtuanya yaitu ayah, ibu dan juga keluarganya. Namun tetap memberikan ruang untuk sosialisasi dengan dunia luar karena perilaku seorang anak tidak akan sepenuhnya mencontoh atau mengcopy begitu saja perilaku, perasaan, cara sudut pandang orangtuanya. Ada proses seleksi yang tidak kasat mata yang terjadi dalam diri anak dengan melibatkan semua fungsi psikologisnya yang berjalan dalam proses yang panjang.

Selama bertahun tahun, sosialisasi antara orang tua dengan anak dipandang sebagai suatu proses satu arah. Anak-anak dianggap sebagai produk dari teknik sosialisasi yang diterapkan orang tua mereka. Akan tetapi dewasa ini, kita memandang interaksi orang tua dan anak sebagai sebuah proses timbal balik. 
ISTIGHNA, Vol. 3, No 2, Juli 2020 P-ISSN 1979-2824 E-ISSN 2655-8459

Homepage: http://e-journal.stit-islamic-village.ac.id/index.php/istighna

Amita Diananda

Kelekatan Anak Pada Orang Tua dalam Meningkatkan Perkembangan Kognitif

dan Harga Diri

Sosialisasi timbal balik (resiprocal-socialization) ialah pandangan bahwa sosialisasi adalah proses dua arah dimana anak-anak bersosialisasi dengan orang tua sama seperti orang tua bersosialisasi pula dengan anak-anaknya. ${ }^{28}$ Dengan kata lain pembentukan kelekatan pada masa kecil mempengaruhi kemampuan anak dalam menjalin hubungan atau persahabatan sampai pada masa dewasa.

Dalam teori perkembangan kognitif Vygotsky mengemukakan bahwa orang dewasa memicu perkembangan kognitif anak-anak dengan melibatkan mereka di dalam kegiatan-kegiatan yang berarti dan kegiatan yang menantang, membantu mereka melakukan kegiatan-kegiatan tersebut berhasil, dan berbicara dengan mereka mengenai pengalaman mereka. Dalam pandangan Vygotsky, dialog dengan orang lain adalah keadaan yang penting untuk memicu perkembangan kognitif, sehingga anak-anak dapat melaksanakan tugas-tugas yang menantang apabila dibantu oleh individu yang lebih maju dan lebih kompeten. ${ }^{29}$

\section{Harga Diri (Self-Esteem)}

Pengertian harga diri (self-esteem) ialah dimensi evaluative global dari diri. Harga diri dapat juga dipahami sebagai suatu kondisi dimana seseorang itu menempatkan dirinya pada posisi yang sepatutnya atau memunculkan suatu citra diri yang patut dihormati atau dihargai. Misalnya, seorang anak dapat merasa bahwa ia tidak sekedar seorang manusia, tetapi juga seorang manusia yang baik. ${ }^{30}$

Harga diri juga berarti pandangan individu tentang dirinya, dan seberapa penting harga dirinya. Jika seorang anak dalam masa hidupnya mendapatkan pujian, motivasi yang membangun, maka akan menjadi pribadi yang baik dan mempunyai harga diri yang baik. Namun sebaliknya jika anak dalam masa hidupnya sering mendapat perlakuan yang tidak baik misalnya dicaci, dihina, diabaikan, tidak dihargai besar kemungkinan ia mempunyai harga diri yang rendah yang bisa berakibat anak nakal membuat ulah, meyakiti teman dan lain-lain karena merasa dirinya tidak berharga.

Harga diri merupakan evaluasi emosional. Aspek ini meliputi; perasaan anak tentang penampilannya, gendernya, posisinya dalam keluarga, dan kemampuannya. Ia harus merasa ia bisa, ia penting, ia berhasil dan berharga. Ia memperoleh perasaan keberhargaan dirinya melalui interaksinya dengan orang lain di sekitarnya serta pandangan penilaiannya terhadap dirinya sendiri dan kemampuannya. ${ }^{31}$

\footnotetext{
${ }^{28}$ John W. Santrock, Life Span Development, (Jakarta: Penerbit Airlangga, 2002), h. 195. Ed.5.Jilid. 1

${ }^{29}$ Teressa M.McDevitt, Jeanes Ellis Ormrod, Op.Cit., h.131-132.

${ }^{30}$ Op cit., h. 356.

${ }^{31}$ Janice J. Beaty, ObservasiPerkembangan Anak Usia Dini (Jakarta: Kencana Prenda media grup, 2010) Cet. ke-1. h. 54.
} 
ISTIGHNA, Vol. 3, No 2, Juli 2020 P-ISSN 1979-2824 E-ISSN 2655-8459

Homepage: http://e-journal.stit-islamic-village.ac.id/index.php/istighna

Amita Diananda

Kelekatan Anak Pada Orang Tua dalam Meningkatkan Perkembangan Kognitif

dan Harga Diri

Untuk meningkatkan harga diri, seorang anak harus mempunyai gambaran diri yang positif yang diawali dengan penerimaan anak tentang dirinya apa adanya (self-accepted). Penerimaan diri ini dimulai dari orang tua menerima anak apa adanya bukan karena nilainya bagus atau bentuk fisik sempurna tetapi karena anak memang berharga. Self-image anak positif maka harga dirinya positif dan berdampak pada percaya diri (confident).

Membangun Self-esteem anak seyogyanya dimulai dari rumah, karena lingkungan rumah adalah lingkungan yang terdekat dengan anak. Orang tua dan lingkungan berperan aktif dalam membantu membangun Self-esteem.

Berikut adalah beberapa cara untuk membangun rasa harga diri yang tinggi pada anak, seperti dikutip Lifemojo: ${ }^{32}$

a. Jadilah pendengar yang baik; Di tengah kehidupan modern saat ini, seringkali orang tua sulit meluangkan waktu untuk anak-anak mereka. Sesibuk apa pun, wajib bagi orang tua untuk membagi waktu bersama anak-anak setiap hari. Tinggalkan semua pekerjaan orang tua, duduk dan bicaralah dengan anak seperti halnya orang tua berbicara dengan orang dewasa.

b. Pujilah anak anda; Anak mungkin datang kepada orang tua untuk menunjukkan suatu keahlian atau hasil ujian yang diperolehnya di sekolah. Berikan pujian kepada anak untuk karyanya, namun jangan berlebihan.

c. Jangan bandingkan; Orang tua sering membandingkan satu anak dengan anak lain atau tetangga dengan maksud bahwa anak dapat berubah dan menjadi seperti yang orang tua harapkan. Cara ini bukan merupakan suatu sikap atau pola pendidikan yang benar karena dapat menggiring anak kepada kondisi atau perasaan rendah diri.

d. Jangan mengkritik terlalu keras; Kritik yang keras selalu membawa hasil yang merugikan. Jika orang tua ingin mengkritik, lakukan dengan kata-kata yang halus dan jangan sampai menyinggung perasaannya.

e. Jadilah contoh; Anak-anak umumnya tidak terlalu bisa banyak mengingat nasihat dari orang tua mereka. Akan tetapi mereka cenderung mengamati perilaku dan sikap orang tua. Jadi, berikanlah panutan yang baik pada anakanak.

Menurut Baumester, Bushman, Cambell, Krueger, dan Vohs (2004), diyakini bahwa ada hubungan yang kuat antara harga diri anak dan keberhasilan mereka di

\footnotetext{
${ }^{32}$ Kompas.com dengan judul "Tips Membangun Harga Diri

Anak", https://nasional.kompas.com/read/2012/01/21/1653516/Tips.Membangun.Harga.Diri.Ana $\underline{\mathrm{k}}$.
} 
ISTIGHNA, Vol. 3, No 2, Juli 2020 P-ISSN 1979-2824 E-ISSN 2655-8459

Homepage: http://e-journal.stit-islamic-village.ac.id/index.php/istighna

Amita Diananda

Kelekatan Anak Pada Orang Tua dalam Meningkatkan Perkembangan Kognitif dan Harga Diri

sekolah. ${ }^{33}$ Dari penelitian ini dapat digambarkan bahwa pembentukan harga diri merupakan proses yang berkesinambungan, tetapi apabila sudah terbentuk dalam suatu kepribadian, akan sulit untuk mengalami perubahan saat anak semakin dewasa. Pendampingan orang tua dalam proses ini tentunnya membutuhkan attachment yang kuat untuk mendukung proses tersebut. ${ }^{34}$

Ada 8 (delapan) butir daftar centang tentang kemajuan harga diri (self-esteem) dengan tahapan yang dilalui banyak anak saat mereka berpisah dari orang tua atau pengasuh utama mereka dan tentang kesulitan menyelesaikan diri dengan usia prasekolah: ${ }^{35}$

a. Berpisah dari pengasuh utama tanpa kesulitan

Keberpisahan anak pada saat awal masuk sekolah seringkali sulit berpisah dari orang tuanya. Berpisah dari orang tua atau pengasuh utama sering kali membuat anak sedih. Setiap anak dalam menghadapi situasi ini berbeda beda. Ada anak yang terus menempel pada ibunya dan menjerit manakala ibunya pergi. Ada anak yang pemalu yang membutuhkan motivasi dari gurunya untuk bergabung dengan kelompoknya, ada juga yang menyendiri dan duduk disudut sambil menghisap jempol dan lain-lain. Peran orang tua dan guru membantu mengembangkan rasa akan eksistensi diri yang kuat sehingga anak merasa nyaman berpisah dari pengasuh utama mereka.

Jika anak belum berhasil merasa aman dalam situasi ini, seorang guru hendaknya menunjukkan penerimaan anak tanpa syarat dengan lewat kata, ekspresi wajah, dan tindakan. Sering tersenyum kepada anak, menyapa dengan kata "senang bertemu kalian", atau mengucapkan "sampai ketemu besok, jangan lupa ya?" atau menunjukkan kepada anak bahwa guru senang kalau berdekatan kepada anak dan meminta anak dekat dengan guru atau dengan cara membacakan sebuah buku dan lain-lain yang menunjukkan rasa kedekatan dengan anak.

b. Mengembangkan hubungan kemelekatan yang aman dengan guru

Anak-anak yang telah membentuk kelekatan aman dengan orang tua atau pengasuh utama mereka biasanya mudah mengembangkan hubungan aman dengan guru mereka juga. Seperti yang Balaban katakan: "saat seorang anak percaya, ia alihkan rasa sayangnya dari orang tua ke guru”. Anak yang melekat aman cenderung menganggap guru pantas dipercaya dan diri mereka pantas disayang.

\footnotetext{
${ }^{33}$ Janice J. Beaty, loc.cit.

${ }^{34}$ Janice J. Beaty, loc.cit.

${ }^{35}$ Ibid., h. 56-78.
} 
Amita Diananda Kelekatan Anak Pada Orang Tua dalam Meningkatkan Perkembangan Kognitif dan Harga Diri

Jika anak masih belum merasa adanya rasa kemelekatan kepada gurunya, maka berikan perhatian secara personal dan positif. Pastikan bahwa guru setiap saat selalu tersenyum dan peduli dengan melakukan pendekatan secara fisik maupun batiniah (psikologis) untuk beberapa menit lamanya dan kemudian guru kembali kepada kegiatannya sendiri.

c. Berhasil dalam menyelesaikan tugas

Anak berhasil dalam menyelesaikan tugas merupakan bagian dari harga diri. Sekecil apapun keberhasilan anak dalam menjalankan tugasnya harus dihargai sebagai suatu pencapaian anak. Misalnya, anak mampu mengikat tali sepatu sendiri walaupun ada yang terlewatkan, misal lubang talinya, atau kurang sempurna dalam mengikat tali sepatunya, namun tetap berikan pujian dengan mengatakan, "lihat itu.! Kamu mengikat tali sepatumu sendiri".

Jika anak masih mengalami kesulitan dalam menyelesaikan tugas maka guru mendampingi sambil memberikan arahan, kemudian biarkan anak mengerjakan sendiri sampai selesai. Beri dukungan lisan positif dan foto hasil karya anak dengan dirinya atau tempel hasil karya di dinding.

d. Melakukan pilihan kegiatan tanpa bantuan guru

Sejumlah kajian seperti yang dikemukakan Mitchell-Xopeland, Denham, DeMuller (1970) mendapati kenyataan bahwa "Anak-anak yang melekat aman pada pengasuh utama mereka akan mendekati teman-teman dengan harapan interaksi dan respon positif. Sebaliknya anak-anak dengan kemelekatan tidak aman pada pengasuh mereka akan menduga dan memulai interaksi kurang optimal".

Jika anak belum mau melakukan kegiatan di kelas, maka berikan cukup waktu anak untuk memilih kegiatan sendiri dan berkeliling dahulu selama periode pilihan bebas. Jangan paksa mereka ikuti kegiatan sebelum mereka siap.

e. Mengajak bermain anak-anak lain

Mengajak bermain anak-anak lain merupakan bagian kemajuan harga diri yang berkembang serta sosialisasi.

Jika anak masih belum siap berinteraksi dengan teman-teman sebayanya, sebaiknya guru membantu untuk mencarikan teman yang mungkin bisa berhubungan empat mata sebelum ia bisa membaur dengan satu kelompok.

f. Bermain percaya diri di permainan drama

Indikator yang berkembang apabila anak sudah mau bermain dengan teman temannya adalah anak bisa menerima dan memainkan peran di situasi 
ISTIGHNA, Vol. 3, No 2, Juli 2020 P-ISSN 1979-2824 E-ISSN 2655-8459

Homepage: http://e-journal.stit-islamic-village.ac.id/index.php/istighna

Amita Diananda

Kelekatan Anak Pada Orang Tua dalam Meningkatkan Perkembangan Kognitif dan Harga Diri

simulatif di program anak usia dini yaitu, pura-pura menjadi ayah atau ibu atau peran menjadi dokter, petani dan lain sebagainya.

Jika anak belum percaya diri dalam permainan drama, sebaiknya guru memberikan contoh dengan memainkan sendiri peran itu sementara waktu, sampai anak siap secara emosional. Jika anak sudah mau menerima arahan guru dan terlihat anak sudah siap dengan teman-teman yang lain, maka guru bisa perlahan-lahan menarik diri.

g. Membela hak sendiri

Anak-anak mungkin membela hak mereka dalam sejumlah cara. Salah satu ciri anak yang memiliki kepercayaan diri tinggi yaitu mempunyai hak memiliki. Hak memiliki ini mempunyai arti bahwa anak sudah mampu mempertahankan miliknya sendiri karena kepercayaan diri yang tinggi akan harga dirinya.

h. Menampilkan antuisme mengerjakan sendiri berbagai hal

Anak sudah mencapai kepastian diri tentang kemampuan mereka sendiri untuk bisa mencoba dan akhirnya berhasil melakukan sendiri berbagai hal.

Jika anak belum antuisme maka guru mendorong munculnya kemampuan bantu- mandiri. Yaitu meminta anak lain ikut membantu menggunakan kancing, resleting dan lainnya, dan berikan cukup waktu bahkan untuk anak yang lambat melakukan sendiri tugas ini.

\section{KESIMPULAN}

Kelekatan anak kepada orang tua adalah suatu keniscayaan. Kelekatan menunjukkan kesan yang mendalam. Orang tua atau pengasuh utama adalah kelekatan pertama anak sejak lahir. Orang tua yang secara konsisten memberikan respon yang dibutuhkan anak, akan membuat anak mempunyai kesan yang menyenangkan (secure attachment) sehingga diharapkan kelak anak mempunyai kematangan dalam berfikir dan dapat membangun relasi yang efektif dengan mempunyai harga diri yang baik. 
ISTIGHNA, Vol. 3, No 2, Juli 2020 P-ISSN 1979-2824 E-ISSN 2655-8459

Homepage: http://e-journal.stit-islamic-village.ac.id/index.php/istighna

Amita Diananda Kelekatan Anak Pada Orang Tua dalam Meningkatkan Perkembangan Kognitif dan Harga Diri

\section{REFERENSI}

Adiyanti, M. G. Attachment Behavior in Children -: Perkembangan kelekatan anak. Tesis. (Yogyakarta: Fakultas Pasca Sarjana Universitas Gadjah Mada, 1989)

Chuy, Wing-Yip \& Leung, Man-Tak. Adult Attachment Internal Working Model of Self and Other, Self Esteem and Romantic Relationship Satisfaction in Chines Culture: By Multilevel-Multigroup Structural Equation Modelling, Applies Psychology Reading (2016). DoI 10.1007/978-981-10-2796_14

Cassidy, J. "The nature of the child's ties. Dalam Handbook of attachment: Theory, research, and clinical application." 2nd ed. J. Cassidy \& P.R. Shaver (Eds.). (New York: The Guildford Press, 2008)

https://www.universitaspsikologi.com/2018/05/teori-psikologi-perkembanganattacment-kelekatan.html

https://asysyariah.com/anak-lahir-di-atas-fitrah/

Hari Santoso. Fitrah Based Education (Bekasi, yayasan Cahaya Timur, 2018)

John W. Santrock. Life-Span Development Perkembangan Masa Hidup, (Jakartra: Erlangga, 2002)

Jeanne Ellis Ormrod. Psikologi Pendidikan, (Jakarta: Penerbit Erlangga, 2008)

John W. Santrock. Life Span Development, (Jakarta: Penerbit Airlangga, 2002)

Janice J. Beaty. ObservasiPerkembangan Anak Usia Dini (Jakarta: Kencana Prenda media grup, 2010)

Kompas.com dengan judul "Tips Membangun Harga Diri Anak", https://nasional.kompas.com/read/2012/01/21/1653516/Tips.Memba ngun.Harga.Diri.Anak.

McConnell, M. \& Moss, E. Attachment across the life span: factors that contribute to stability ang change. Australian Journal of Educational \& Developmental Psychology

Novan Ardy Wiyani. Psikologi Perkembangan Anak Usia Dini (Yogyakarta: Gava Media, 2014)

Okina Fitriani. Enlightening Parenting (Jakarta: PT Serambi alam semester,2018)

P.J Monk, A.M.P. Knoers, (et.all). Psikologi Perkembangan, (Yogyakarta: Gadjah mada Universyty Phress)

Padang Mursalin, dkk. Psikologi (Jakarta: Penerbit Erlangga, 2016) 
ISTIGHNA, Vol. 3, No 2, Juli 2020 P-ISSN 1979-2824 E-ISSN 2655-8459

Homepage: http://e-journal.stit-islamic-village.ac.id/index.php/istighna

Amita Diananda Kelekatan Anak Pada Orang Tua dalam Meningkatkan Perkembangan Kognitif dan Harga Diri

S.R.R. Pujiati dan Alzena Masykouri. Mengasah Kecerdasan di usia 0-2 Tahun (Jakarta: Dirjen PAUDNI, 2011)

Teressa M McDevvit, Jeanes Elliss Omrod. Child Development and Education (New Jersey Colombo, Ohio, Merril Prentice Hall, 2002)

Winarti, Kholilawati \& Istianti, Hubungan Kelekatan Orangtua Dengan Anak Terhadap Kecerdasan Emosional Remaja laki-laki di SMP, JKKP: Jurnal Kesehatan Keluarga dan Pendidikan, (2014) DOI:doi.org/10.21009/JKKP.012.03 